\section{OPEN ACCESS \\ Edited by: \\ Maria Illhéu,}

University of Evora, Portugal

Reviewed by:

Pedro Giovâni Da Silva,

Federal University of Minas Gerais, Brazil Rabi Mohtar,

American University of Beirut, Lebanon Jürgen Mahlknecht,

Tecnológico de Monterrey, Mexico

*Correspondence:

Vinicius F. Farjalla

vinicius.farjalla@gmail.com

tORCID:

Vinicius F. Farjalla orcid.org/0000-0003-4084-5983 Aliny P. F. Pires

orcid.org/0000-0002-7736-8802

Angelo A. Agostinho

orcid.org/0000-0002-4707-9444

André M. Amado

orcid.org/0000-0002-7736-8802

Reinaldo L. Bozelli

orcid.org/0000-0001-9916-1629

Viviane Dib

orcid.org/0000-0001-5457-5983

Angelo J. R. Lima

orcid.org/0000-0003-1488-361X

Roger P. Mormul

orcid.org/0000-0001-9020-4784

Jean P. H. B. Ometto

orcid.org/0000-0002-4221-1039

Renata Panosso

orcid.org/0000-0002-2704-069X

José Sabino

orcid.org/0000-0001-9160-9441

Daniel A. Rodriguez

orcid.org/0000-0002-1054-1252

Fabio R. Scarano

orcid.org/0000-0003-3355-9882

Specialty section:

This article was submitted to

Freshwater Science,

a section of the journal

Frontiers in Environmental Science

Received: 17 June 2021 Accepted: 02 November 2021

Published: 08 December 2021

Citation:

Farjalla VF, Pires APF, Agostinho AA, Amado AM, Bozelli RL, Dias BFS, Dib V, Faria BM, Figueiredo A, Gomes EAT, Lima ÂJ, Mormul RP, Ometto JPHB,

Panosso R, Ribeiro MCLB,

Rodriguez DA, Sabino J, Scofield $V$ and

Scarano FR (2021) Turning Water

Abundance Into Sustainability in Brazil.

Front. Environ. Sci. 9:727051.

doi: 10.3389/fenvs.2021.727051

\title{
Turning Water Abundance Into Sustainability in Brazil
}

Vinicius F. Farjalla ${ }^{1 * t}$, Aliny P. F. Pires ${ }^{2 t}$, Angelo A. Agostinho ${ }^{3 t}$, André M. Amado ${ }^{4 t}$, Reinaldo L. Bozelli ${ }^{1 \dagger}$, Braulio F. S. Dias ${ }^{5}$, Viviane Dib ${ }^{6+}$, Bias M. Faria ${ }^{7}$, Andrea Figueiredo ${ }^{8}$, Eli A. T. Gomes ${ }^{9}$, Ângelo J. R. Lima ${ }^{10 t}$, Roger P. Mormul ${ }^{11 t}$, Jean P. H. B. Ometto ${ }^{12 t}$, Renata Panosso ${ }^{13 t}$, Mauro C. L. B. Ribeiro ${ }^{14}$, Daniel A. Rodriguez ${ }^{15 t}$, José Sabino ${ }^{16 t}$, Vinicius Scofield ${ }^{17}$ and Fabio R. Scarano ${ }^{1+}$

\begin{abstract}
${ }^{1}$ Departamento de Ecologia, Instituto de Biologia, Universidade Federal Do Rio de Janeiro, Rio de Janeiro, Brazil, ${ }^{2}$ Instituto de Biologia Roberto Alcantara Gomes, Universidade Do Estado do Rio de Janeiro, Rio de Janeiro, Brazil, ${ }^{3}$ Programa de PosGraduação Em Ecologia de Águas Continentais, Universidade Estadual de Maringá, Maringá, Brazil, ${ }^{4}$ Departamento de Biologia, Instituto de Ciências Biológicas, Universidade Federal de Juiz de Fora, Juiz de Fora, Brazil, ${ }^{5}$ Departamento de Ecologia, Universidade de Brasilia, Brasilia, Brazil, ${ }^{\circ}$ International Institute for Sustainability, Rio de Janeiro, Brazil, ${ }^{7}$ PETROBRAS, CENPES/ PDIDMS/SE/MCA, Av. Horácio Macedo, Cidade Universitária, Rio de Janeiro, Brazil, ${ }^{8}$ Departamento de Ecologia, Instituto de Biociências de Rio Claro, Associação Brasileira de Limnologia (ABLimno), Universidade Estadual Paulista (UNESP), Rio Claro, Brazil, ${ }^{9}$ Biosustente Estudos Ambientais, Rio de Janeiro, Brazil, ${ }^{10}$ Observatório da Governança Das Águas, São José Dos Campos, Brazil, ${ }^{11}$ Universidade Estadual de Maringá, UEM, Maringá, Brazil, ${ }^{12}$ Instituto Nacional de Pesquisas Espaciais (INPE), São José Dos Campos, Brazil, ${ }^{13}$ Department of Microbiology and Parasitology, Federal University of Rio Grande do Norte, Natal, Brazil, ${ }^{14}$ Reserva Ecológica Do IBGE, Brasilia, Brazil, ${ }^{15}$ Alberto Luiz Coimbra Institute for Graduate Studies and Research in Engineering, University of Rio de Janeiro, Rio de Janeiro, Brazil, ${ }^{16}$ Universidade Anhanguera Uniderp, Campo Grande, Brazil, ${ }^{17}$ Ministério Do Meio Ambiente, Esplanada Dos Ministérios, Brasília, Brazil
\end{abstract}

Brazil is a powerhouse in terms of water resources, which are instrumental to the country's transition to sustainability. However, to realize this potential, substantial management and conservation hurdles must first be overcome. We propose a novel strategy for the use, management, and conservation of Brazilian water resources. Our approach recognizes the spatial heterogeneity of water abundance and is based on a multisectoral perspective, including energy, food, sanitation, and environmental conservation. The main recommendations are to adopt low-cost local and subnational solutions and to design policy mixes, both based on the logic of the nexus water-food-energy-ecosystem. We offer as examples programs that 1) increase cistern infrastructure in drylands, 2) use constructed wetlands to improve sewage treatment in small cities and vulnerable areas, 3) turn the focus of conservation to aquatic ecosystems, 4) stimulate the adoption of small hydrokinetic turbines for energy generation in sparsely populated river-abundant regions, such as the Amazon Region, 5) diversify the matrix of renewable energy sources by combining hydropower with biomass and wind energy generation, and 6) mixes policies by integrating multiple sectors to improve regulation, use and management of water resources, such as the Brazilian "Water for All" Program. By following these recommendations, Brazil would align itself with the goals established in international agreements and would turn its abundance of water resources into development opportunities.

Keywords: nexus approach, water resources, policy mixes, hydropower, constructed wetlands, protected areas 


\section{INTRODUCTION}

Sustainability has emerged as an agenda able to integrate multiple dimensions of human wellbeing. Considering the 2030 Agenda proposed by the United Nations through the Sustainable Development Goals (SDG), it is urgently necessary to integrate environmental, social, and economic sectors to reach sustainable development. The paths countries must follow to achieve sustainability will depend on the specific challenges and opportunities that each country faces (Pires et al., 2021). Overall, biosphere components of sustainability are considered the base of such transformative change and they can speed up social and economic outcomes (Folke et al., 2016; Obrecht et al., 2021). Megadiverse countries rich in natural resources would have advantages in designing their strategy to reach sustainability (Scherer et al., 2018). The greatest challenge for these countries is to define how to transform their natural capital into a true path to sustainability (Wood et al., 2018; Mahlknecht et al., 2020; Pires et al., 2021).

Water is a key element in integrating sustainability dimensions and thus can trigger transformations in society. Brazil leads the world in the amount of renewable internal freshwater resources ( $12 \%$ of total global), including the Amazon and Pantanal-two of the most extensive wetlands in the world. In terms of inland water biodiversity, Brazil harbors more than 3,000 fish species, accounting for more than $20 \%$ of the world's freshwater fish biodiversity (Tedesco et al., 2017). Although Brazil is only 26th globally in terms of renewable water availability per person, most of these water resources ( $>90 \%)$ are underutilized. These water resources support the Brazilian economy, the ninth largest in the world. For example, agribusiness depends on rainwater and surface irrigation and represents more than $20 \%$ of the Brazilian Gross Domestic Product, and hydropower is the backbone of the Brazilian electricity generation, producing around $65 \%$ of total electricity (EPE, 2021). Therefore, the abundance and potential use of water resources can leverage the Brazilian transition into sustainability. However, Brazil must first overcome hurdles in the conservation and management of water bodies related to uneven distribution of water, divergent policies on water management, fragile public governance, and anthropogenic impacts.

\section{THREATS TO AND OPPORTUNITIES GENERATED BY BRAZILIAN WATER RESOURCES}

Brazil's territory spans over 38 degrees of latitude $\left(5^{\circ} 16^{\prime} 20^{\prime \prime} \mathrm{N}\right.$ to $\left.33^{\circ} 45^{\prime} 03^{\prime \prime} \mathrm{S}\right)$ and 39 degrees of longitude $\left(34^{\circ} 47^{\prime} 34^{\prime \prime} \mathrm{W}\right.$ to $\left.73^{\circ} 59^{\prime} 26^{\prime \prime} \mathrm{W}\right)$. Brazil is divided into five different regions, which strongly vary in relation to climate, relief, vegetation and the availability of surface water (Figure 1A). For example, while the North Region is characterized by large floodplain rivers and an evergreen equatorial forest, the Northeast Region is characterized by a semiarid climate, low surface water and predominantly xerophytic vegetation. Besides climate differences, variation in population density (Figure 1B) results in great differences in the availability of water resources among Brazilian Regions. The North Region has great surface water availability and low population density (IBGE, 2020; Figure 1B). The Southeast and South Regions have a humid climate but a very high population density (IBGE, 2020; Figure 1B). The interaction between low surface water availability and high rates of water withdrawal for consumptive uses (e.g., human consumption, agriculture, animal watering, industry) results in critical to very critical quantitative water balance in most of the Northeast Brazilian region (ANA, 2020; Figure 1C). Other critical and very critical areas are present in Southeast and Midwest regions, characterized by low precipitation and high agricultural consumption, and in the extreme south of the South Region, due to the high consumption of rice plantations (Figure 1C).

Differences in population density, water availability and water demand among regions result in different threats to aquatic environments and aquatic biodiversity (Figure 1D). Threat levels to water resources in Brazil are strongly correlated to land use changes, which includes the presence of large cities and the conversion of natural areas for agricultural and livestock production (BPBES, 2020). Despite having a secure situation in relation to water resources, the North Region is in the global spotlight due to the increase in degradation and deforestation rates and the projects of large hydroelectric dams (Latrubesse et al., 2017; Matricardi et al., 2020). Information on the threat levels to aquatic biodiversity in the Northeast Region is still scarce, mainly in interior areas with less water availability, however, where information is present, the levels are usually high (Figure 1D). The eutrophication of small dams and water holes and the increase in the intensity of drought events due to climate change result in critical levels of water security in the region, pushing for the integration of climate and water policy (Milhorance et al., 2021). The Southeast Region concentrates the largest part of the Brazilian population and important areas of agricultural and industrial production. The highest levels of threat observed in the Southeast Region (Figure 1D) is mainly explained by pollution and excessive water withdrawal for consumptive uses that should worsen in the coming decades due to climate change. For instance, the Guandu basin - the main water supply for the urban area of Rio de Janeiro-should receive les less transferred water from adjacent basins due to low rainfall and higher demand of hydropower energy produced in the adjacent basins (González-Bravo et al., 2020). The Midwest region is the main Brazilian grain-producing region and most of the threats to aquatic biodiversity and aquatic environments are related to changes in land use and pollution by agricultural fertilizers. Finally, the South Region has moderate to high levels of threat to aquatic biodiversity (Figure 1D), mainly due to excessive water withdrawal for consumptive uses and the presence of invasive species in its main water basins. Taking together, we estimated around $40 \%$ of the Brazilian territory presents moderate to high threat levels of aquatic environments (Figure 1D).

Although the differences among regions within the country impose multiple challenges to manage water resources at national level, they provide a fruitful environment of conditions that allow establishing cost-effective strategies at sub-national or local 


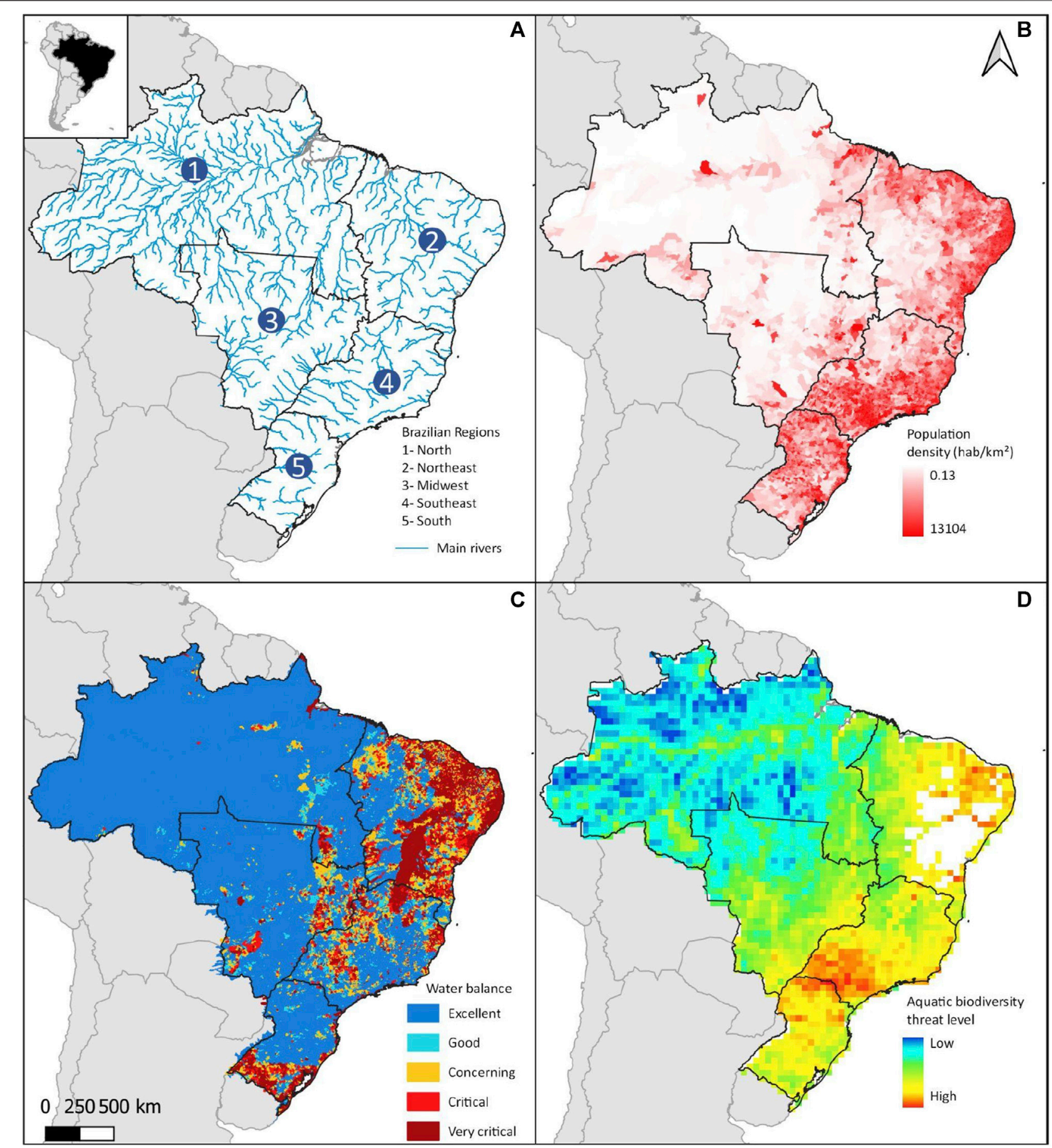

FIGURE 1 | Characterization of the Brazilian geographic regions according to (A) the surface water availability, exemplified by the main hydrographic basins (adapted from ANA, 2021); (B) the population density (people per sq. km of land area; data from the Brazilian Institute of Geography and Statistics - IBGE); (C) the quantitative water balance (adapted from ANA, 2021); and (D) the threat levels to aquatic biodiversity (adapted from Vörösmarty et al., 2010). The quantitative water balance was obtained at the micro-basin scale, through the ratio between the withdrawal for consumptive uses (industry, irrigation, urban supply and livestock watering) and the water availability. The threat levels to aquatic biodiversity in Brazil was based on the global threat index of aquatic biodiversity, which combines 23 stressors according to their impacts on aquatic biodiversity (Vörösmarty et al., 2010). The Brazilian semi-arid region was not considered in this analysis as it is classified as a desert region (Vörösmarty et al., 2010). About $40 \%$ of the Brazilian territory showed threat levels from moderate to high. 
scales. In fact, most of the challenges in managing water resources and effective policy are at the sub-national or local scales rather than larger, national scales (Green et al., 2017). Thus, by considering the multiple conditions of water resources in Brazil, it is possible to identify how to integrate the water agenda with other critical components of sustainability such as food, energy and biodiversity conservation. The integration of such complex and intertwined dimensions of human wellbeing is addressed in the nexus approach (Liu et al., 2018a; Mercure et al., 2019) that reinforces the importance of accessing multisectoral solutions and policy mixes to improve management and conservation of water resources.

Nexus approaches could support a resource effective management strategy by enhancing synergisms and interlinkages, and potentially reducing negative trade-offs among multiple sectors (Liu et al., 2018a; Mercure et al., 2019). As water resources regulate and are impacted by various sectors (e.g., agriculture, people, trade, energy, finance, climate) nexus approaches were first highlighted for the management and conservation of aquatic environments by the World Economic Forum (2011) and at the Bonn 2011 Nexus Conference (Hoff, 2011), and have since been used in several other studies (e.g., Bijl et al., 2017; Heard et al., 2017; Kaddoura and El Khatib, 2017; Liu et al., 2018b). Nexus approaches are considered particularly relevant in tropical countries, due to the overspread economic difficulties and their role in the global environment and food security (Wallington and Cai, 2017; Mahlknecht et al., 2020).

Identifying the potential and challenges of the nexus approaches implementation would allow Brazilian waters to turn into a pathway to sustainability. Despite the nexus approach can be discussed by considering different perspectives, energy, food, and biodiversity conservation are key elements to discuss water management in Brazil. As we show below, Brazil has a great potential to incorporate local low-cost solutions that result in positive synergies in more than one sector (e.g., cost-effective rainwater storage systems and constructed wetlands). Also, the current interactions and synergies present in established policy instruments may favor designing new policy mixes. In sum, Brazil offers good hints on how nexus approaches can transit across different governance scales, by considering the support of legal instruments at national level and the implementation of water-related social technologies. By ensuring the existence of a consistent institutional framework for water management and conservation that incorporates multiple sectors and tools that allow the implementation of cost-effective solutions to local water-related problems, Brazil can design a water nexus model to be replicated worldwide.

\section{INSTITUTIONAL FRAMEWORK OF WATER MANAGEMENT AND CONSERVATION IN BRAZIL}

The governance and use of water resources in Brazil are mainly regulated by the National Water Resources Policy (NWRP, Law n. 9,433/1997), which defines the guidelines, instruments, and the role of national and local government agencies in the management of water resources. Nexus approaches are present in the foundations of NWRP, by defining water as a common good, by addressing the multiple uses of aquatic ecosystems, by establishing a decentralized and participative management of water resources, and by focusing the management of water resources on the hydrographic basins (Veiga and Magrini, 2013; Trimble et al., 2021). NWRP also determines the preparation of Water Resources Plans for each hydrographic basin. These plans must include a diagnosis on the current situation of water sources and the balance between their availability and current and future demands, and must define long-term goals for the rational use and the improvement in the water quality of aquatic ecosystems. Instruments for granting use rights and charging for the use of water resources are also present in the national policy, promoting the achievement of long-term goals (Veiga and Magrini, 2013).

However, the governance of water resources considering multiple sectors is challenging. Water management is shared between federal, state and municipal governments in Brazil (Miranda and Reynard, 2020). At the federal level, the government, through the National Water Agency, is responsible for developing the National Water Resources Plan, granting water use permits, setting tariffs and maintaining information systems of water use and its quality (Law n. 9,994/2000). State governments establish their own water councils and agencies with equivalent attributions to the federal ones. Municipal governments act mainly in water supply and sewage treatment. The NWRP also provides for the establishment of River Basin Management Committees, formed by representatives of government agencies, water users and civil society organizations, which approve and monitor the implementation of the Water Resources Plans, propose water use tariffs and arbitrate conflicts between users.

The implementation of the NWRP is the responsibility of the Ministry of Regional Development, but other Ministries and government agencies also influence water management in Brazil. Keys to the water-energy-food-ecosystem nexus perspective are the Ministry of Mines and Energy, which plans and authorizes the construction of hydropower plants, the Ministry of Agriculture, Livestock and Food Supply, which develops aquaculture projects in rivers and reservoirs, and the Ministry of the Environment, which coordinates the federal environmental licensing and the establishment and management of protected areas. Some recent legislative changes will also influence water management in Brazil. For instance, the recently reviewed National Basic Sanitation Plan (PLANSAB, Law n. 14,026/2020) aim to increase from 82 to $99 \%$ of the population the access to drinking water, and to increase from 46 to $90 \%$ of the population the access to sewage collection by 2033 . To achieve these goals, the law supports the privatization of state sanitation companies, the regionalization of water-related services and changes in local regulations (Narzetti and Marques, 2021).

The downside of having multiple sectors operating in the management of water resources in Brazil is the lack of integration between sectoral policies which results in fragmented governance 


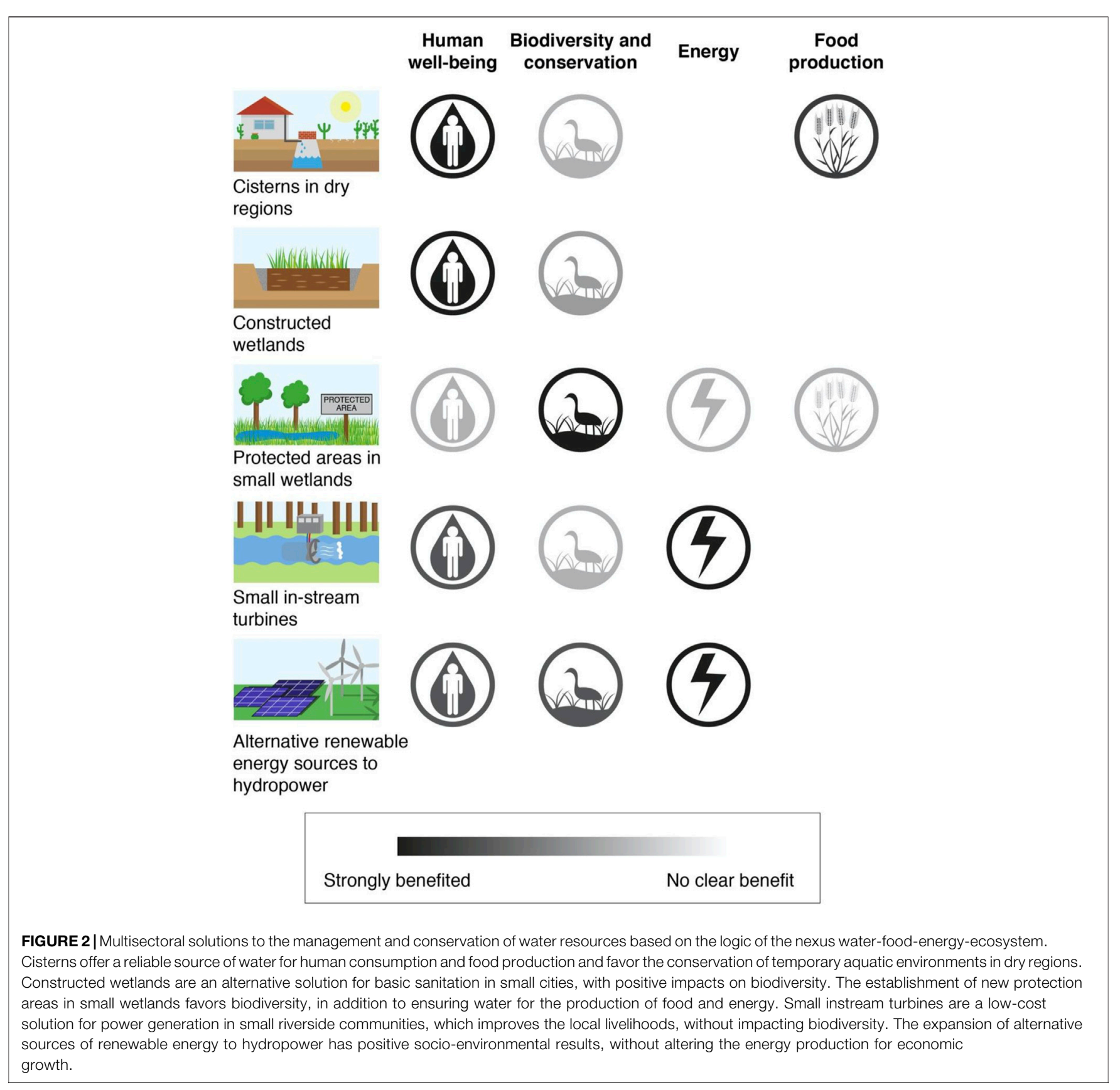

(Carvalho and Spataru, 2018). In sum, Brazil has an extensive legal framework and several government agencies operating in the management of water resources, but the lack of integration has proved to be a problem (Sampaio and Sampaio, 2020). The development of policy mixes built by different sectors based on the nexus approach can push the country to achieve the sustainability goals established in national policies and international agreements. In the next section, we discuss some key mechanisms revealed by practical actions being implemented in Brazil that can accelerate the use of nexus approaches in water management.

\section{IMPLEMENTING NEXUS APPROACH INTO BRAZILIAN WATERS}

While integrating multiple agendas is critical to sustainability, identifying practical examples of how nexus approaches can take place on the ground is challenging. Brazil has had some initiatives that share how the management of water resources for a specific use positively affected other uses, configuring clear cases of nexus approach (see below). These initiatives reduced poverty, improved the renewable energy matrix and promoted biodiversity conservation in Brazil. 


\section{A Water-Related Social Technology to Reduce Hunger and Poverty}

Brazil's Cistern Program developed by the Ministry of Regional Development has promoted access to water for human consumption, agricultural production and livestock watering in the Brazilian semi-arid region through the implementation of low-cost technologies (Doss-Gollin et al., 2016; Figure 2). With an estimated unitary cost of $\sim$ US\$ 650, cisterns for water consumption (first water cisterns; 10,000 to 20,000 of capacity) allow rural families of up to five people to harvest rainwater in the wet season and store it during the drought months, improving their access to a predictable source of drinking water (da Mata et al., 2021). Additional larger-sized systems (second water cisterns; 50,000 to 500.000 of capacity, up to US\$3,000 of implementation costs) allows farmer groups to grow crops and raise livestock for both consumption and sale, improving food security and providing extra income for the families (Cavalcante et al., 2020). Boardwalk cisterns, underground dams, trench dams and stone tanks are other similar low-cost technologies related to the Cistern Program used to store water in the Brazilian semi-arid region (Lindoso et al., 2018; Silva et al., 2021). Trench dams and stone tanks also provide potential refuge for aquatic species but their effects on biodiversity conservation remains to be explored.

More than 1.3 million cisterns have been built, serving approximately 5 million people living in the Brazilian semiarid region (da Silva, 2019), which represent about $50 \%$ of the local population potentially affected by recurring drought events. The cooperation between the federal and local governments and local civil society organizations was pointed out as a key factor for the adoption of the technology (Lindoso et al., 2018). This Program was considered a fundamental reason why Brazil was not placed on FAO's Hunger Map, and it is also an important adaptive strategy to climate change (Gutiérrez et al., 2014; DossGollin et al., 2016). Other social benefits include reducing child mortality, decreasing illiteracy and curbing rural exodus. Following the Brazilian example, FAO launched in 2019 the " 1 million cisterns for the Sahel" initiative by promoting South-South cooperation to improve the resilience of vulnerable communities in Africa. Despite its success, the Cisterns Program is under threat due to the budget reduction by the current federal government. For example, the budget allocated to the Cisterns Program was less than 1 million in 2020, a decrease of more than $95 \%$ of the amount budgeted for the program in 2014 .

\section{A Nature-based Solution for Water to Ensure Sanitation and Health}

Brazil recently reviewed its sanitation legal framework with a new National Basic Sanitation Plan (PLANSAB; MDR, 2019). The PLANSAB foresees the collection and treatment of sewage of $90 \%$ of the Brazilian population by 2033 without differentiating urban, rural areas or informal areas. However, the increase in sewage collection and treatment foreseen in the PLANSAB is expected to mainly occur in urban areas, due to the proportionally higher cost of infrastructure implementation and the lower political appeal of marginal areas (Narzetti and Marques, 2021).
Constructed wetlands are a well-known effective way to improve sewage treatment in small cities and vulnerable areas with less than 20,000 inhabitants (Kivaisi, 2001), which accounts for more than $2 / 3$ of the Brazilian municipalities. This low-cost green technology embodies the circular economy concept and contributes to Sustainable Development Goals and Ramsar Convention commitments (Figure 2). For instance, the combined costs of installing and operating a constructed wetland system for 25 years varied between 25 and $55 \%$ of the total costs of installing and operating conventional sewage treatment systems over the same period (Gray, 2008). Additionally, constructed wetlands use about 15\% the energy of conventional sewage treatment systems (Nelson et al., 2001). According to these authors, if widely applied in developing countries, constructed wetland would represent savings of $75 \%$ of total energy and at least $25 \%$ of the total costs compared to conventional sewage treatment systems (Nelson et al., 2001).

Constructed wetlands are particularly recommended for tropical countries, where plant growth is not seasonally limited by temperature or sunlight (Kivaisi, 2001). In Brazil, however, constructed wetlands have been inexplicably overlooked as a potential solution for sewage treatment in small cities and vulnerable areas, for example being omitted from the PLANSAB (Narzetti and Marques, 2021). We strongly support constructed wetlands being encouraged in the competition for new ventures through policy instruments mainly in small cities and rural and vulnerable areas, such as tax incentives and government subsidies.

\section{Protecting Biodiversity to Foster Aquatic Ecosystem Service}

Brazil has $17 \%$ of its territory within protected areas and an additional 14\% within Indigenous lands (both PAs, hereafter, see Pacheco et al., 2018), most of them supported by the National System of Conservation Units. Besides safeguarding biodiversity, PAs partially support hydroelectricity and agriculture with, respectively, 26 and $4 \%$ of their total water demand (Medeiros et al., 2011), a clear case of synergism for land use (Figure 2). Although the total PA is higher than suggested in the Target 11 of the Convention of Biological Diversity (Aichi Target 11), PAs are mainly located in the Amazon biome (50\% of the Brazilian Amazon) while other biomes are much less protected (average of $<10 \%$ of total area; Azevedo-Santos et al., 2019). To enhance the expansion of PAs in Brazil, we propose that freshwater conservation must be a key element in designing priority areas. For instance, by considering both terrestrial and aquatic biodiversity on planning the establishment of new UCs, freshwater benefits could be increased by up to $600 \%$ for a $1 \%$ reduction in terrestrial benefits (Leal et al., 2020).

There are many small wetlands with substantial potential for conservation scattered throughout the Brazilian territory (Azevedo-Santos et al., 2019). These small wetlands house unique biodiversity, provide resources and leisure options for local populations, and, in many cases, have high tourist potential (Junk et al., 2014; Figure 2). In the Brazilian Savanna region, the region of Bonito earned approximately U\$ 60 million with 
ecotourism per year, most of this income driven by the beauty of the region's aquatic environments (Sloan et al., 2012). This successful case has great potential for replication in other biomes, such as Pantanal and Pampa grasslands. Additionally, the implementation of two laws should increase the protection of Brazilian aquatic ecosystems, with potential synergies in the income of small rural producers, in the generation of hydroelectric energy and in human well-being in areas affected by recurrent droughts.

The recently reviewed National Policy on Payment for Environmental Services (Law n. 14,119/2021) focuses on biodiversity conservation associated with income generation for small landowners, through charging for the provision of ecosystem services. Its main goal is providing financial incentives for activities that support the maintenance, recovery or improvement of ecosystem services. These ecosystem services mainly include those related to water security in semi-arid regions, such as the conservation and recovery of native vegetation and the adoption of sustainable agricultural practices. In Brazil, the Water Producer Program established by the Water National Agency is a successful example of payment for ecosystem service focusing on water-related services that have incorporated over 40 individual projects since its implementation (ANA, 2021). For instance, by the Water Produce project - the first Payment for Environmental Services Program established in Brazil-1.3 million native trees were planted and more than 6,300 ha around water bodies were protected in Extrema municipality, in the Brazilian Southeast Region (Richards et al., 2015). A major outcome of this project was the increase of water recharge in the Jaguari river, which flows into the main reservoir of São Paulo State, the most populated region of Brazil. However, the Water Producer program still fails into providing quantitative estimates of the water yield outcome of most of its related projects. In fact, most of the payment for ecosystem services initiatives are focused on water-related benefits but with measurable and significant co-benefits (Viani et al., 2018).

The Brazilian Native Vegetation Protection Law (NVPL; Law n. 12,651/2012) supports the permanent protection and restoration of riparian vegetation, for maintaining baseline river fluxes, enhancing downstream water quality and promoting habitat connectivity. NVPL defines that the area of the riparian vegetation to be protected or restored depends on water body type and it increases with the river width. The restoration of the riparian protected area projected by the NVPL would boost the achievement of important international agreements, such as the National Determined Contributions to reduce carbon emission established by the Paris Agreement (Rezende et al., 2018). For instance, the riparian area to be restored in the Atlantic Forest biome is around 7.2 Mha, over half of the Brazilian contribution goal of 12 Mha (Rezende et al., 2018). Restoration of riparian vegetation can also contribute to recovering water quality in degraded watersheds (Pires et al., 2017). Therefore, conservation of small wetlands and the protection and restoration of riparian vegetation would promote synergy among biodiversity conservation, carbon sequestration, water supply, disaster risk reduction, food security and cultural options, with minimal direct damage to agriculture through loss of arable land (Rezende et al., 2018).

\section{Combining Hydropower With Other Renewable Energy Sources to Improve Sustainability}

Local solutions are also found for the generation of renewable energy (Figure 2). Micro-hydropower based on hydrokinetic turbines (instream turbines) are a suitable green technology to alleviate costs and meet local energy demands (VanZwieten et al., 2015). This technology is particularly suitable for sparsely populated riverabundant regions such as some areas in Nepal, Indonesia, India, Phillipinas and Bolivia (Erinofiardi et al., 2017; Butchers et al., 2021; Nag and Sarkar, 2021). Positive impacts of implementation of microhydropower turbines in local communities were observed in education, community engagement and economy (Arnaiz et al., 2018). A clear limitation of using this technology in tropical streams and rivers is the large number of debris, since tropical rivers normally flow through thick forests collecting lots of leaves, branches and tree trunks (van Els and Brasil Junior, 2015). Seasonal differences in the water flux can also cause energy supply shortages in drier periods (van Els and Brasil Junior, 2015).

In Brazil, there is an urgent need to apply low-cost solutions for the supply of energy to rural Amazonian communities, which account for more than 6 million people in more than 5 million square kilometers. Most of these communities are excluded from the Brazilian integrated energy system and are generally dependent on expensive and polluting small diesel-powered generators. Interestingly, these communities are usually riverside communities, as rivers are the main sources of food and transport in the region. Here, we strongly support the implementation of low-cost micropower hydrokinetic turbines developed to tropical regions (see exemples in van Els and Brasil Junior, 2015) to supply the small and scattered Amazon riverside communities with energy. Later generations of micropower hydrokinetic turbines promise to alleviate problems with debris and seasonal variation in water flow (van Els and Brasil Junior, 2015). Despite the high installation costs, the low maintenance costs of hydrokinetic turbines would result in overall savings of $20-57 \%$ compared to diesel generators in an Amazonian community (Quintas et al., 2012). Other positive impacts are related to the local alleviation of pollution by diesel generators and the improvement of social well-being (e.g., Arnaiz et al., 2018). As far as we know, the technology of micro-hydropower plants has not been used in the Amazon region, although studies had pointed out its potential impact on the renewable energy generation in the region for almost 35 years (Nogueira et al., 1993; Blanco et al., 2008; van Els and Brasil Junior, 2015).

In 2020, hydropower made up more than $65 \%$ of Brazil's electricity generation (EPE, 2021). The high contribution of hydropower to the electricity generation is why Brazil achieved the SDG 7, which is related to the production of clean energy (Lima et al., 2020). Thus, Brazil largely relies on its water resources for energy supply. The Amazon region is in the focus of discussions on increasing the hydroelectricity generation in Brazil. The expansion of the hydroelectric sector 
in the Brazilian Amazon basin currently relies on large plants designed to address nationwide demand (Latrubesse et al., 2017). Several of these projected plants are based on establishment of large water reservoirs, which are not an adequate option considering the water-food-energy-biodiversity nexus approach due to the disruption of the aquatic and terrestrial systems, emission of greenhouse gases, and negative changes to the livelihood of indigenous peoples and traditional communities (Latrubesse et al., 2017; Moran et al., 2018; Mercure et al., 2019). Given that renewable energy is key to achieving Brazilian reduction targets of greenhouse gas emissions and sustainable development goals (Mahlknecht et al., 2020), we support three subsequent alternative paths for the development of hydropower in Brazil, besides the local use of small instream turbines: 1) replacing the expected growth for the hydroelectric sector with lower impact renewable energy sources such as biomass wind and solar (Figure 2), 2) if no other option available, to instead focus on small hydroelectric plants, and 3) in the last case, the systematic planning for the eventual implementation of new large hydroelectric plants.

In the systematic planning for new large hydroelectric plants, the emission of greenhouse gases must be minimized, the value of biodiversity and cultural diversity must be considered, and the negative socio-environmental externalities must be internalized through local compensations (Moran et al., 2018; Almeida et al., 2019). For instance, placing hydropower dams only in higher elevations and smaller streams in the Amazon basin, Brazil would be within the energy-related SDGs (Almeida et al., 2019). Other recommendations on the installation of large plants include: 1) environmental and social impact assessments must be conducted by groups that are not directly benefited by the project and must be able to stop the project if costs suppress the benefits, 2) the design of the dams must allow the passage of migratory fish and 3) great transparency in the dialogue of the socio-environmental impacts of dams with local societies (Moran et al., 2018). Small hydroelectric plants (usually generating $<10 \mathrm{MW}$ ) have received great attention by the Brazilian government as they seem to be a better alternative to large plants in relation to their socioenvironmental impacts (EPE, 2021), but these impacts are still to be fully evaluated (da Silva eta al, 2016; Moran et al., 2018). Despite the smaller size, it is postulated that small hydroelectric plants would locally have the same impacts of large dams (Okot, 2013; da Silva et al., 2016). Finally, run-of-river projects should be preferred over impoundment projects, although run-of-river projects may also cause decreases of water quantity and quality downstream of the diversion, connectivity loss, habitat degradation and simplification of biological communities (Kuriqi et al., 2021). For instance, all these impacts were observed in the Belo Monte hydroelectric dam complex, located at Xingu River, one of the main tributaries of the Amazon River in Brazil (e.g., Ribeiro and Morato, 2020; Mayer et al., 2021).

Considering the socio-environmental impacts of hydroelectric plants, their established large contribution to the Brazilian electricity matrix and the need to increase the supply of clean energy, we strongly support the increased contribution of alternative renewable energy sources, such as biomass and wind energy, to the Brazilian electricity matrix. In this sense, we echo the findings of Santos and coauthors, who observed, by applying a questionnaire to experts on scenario evaluation processes and by using a multi-criteria decision analysis tool, that the preferable option for the future Brazilian power sector is a scenario where wind and biomass have a major contribution (Santos et al., 2017). A greater diversification of renewable energy sources in the Brazilian electricity matrix is also recommended due to changes in rainfall patterns related to global climate change (Lucena et al., 2018).

Biomass is a renewable energy resource derived from photosynthetic organisms. These organisms grow uptaking inorganic carbon and fixing it into organic carbon in plant biomass. Biomass is considered a renewable source since the inorganic carbon consumed by photosynthetic organisms is the same produced by burning biomass to generate energy. Additionally, biomass offers several benefits: it embodies circular economy concepts, alleviates pollution, reuses agricultural waste and encourages silviculture (Pereira et al., 2012; Teixeira et al., 2018). In Brazil, biomass already accounts for more than $10 \%$ of the total energy matrix, which is mainly related to the ethanol production for fuel from sugarcane (EPE, 2021). In the Brazilian electricity matrix, the contribution of energy from biomass is still low but has been increasing in recent years. Between 2019 and 2020, the contribution of biomass increased from 54.7 TWh to $58.8 \mathrm{TWh}$, an annual increase of more than $7 \%$, reaching more than $9.0 \%$ of the total electricity generated in Brazil (EPE, 2021). This increase is related to the greater use of sugarcane bagasse for thermoelectricity and new biomass thermoelectric plants related to forestry projects (Teixeira et al., 2018; EPE, 2021). Additionally, the contribution of biomass energy is foreseen to increase by about $10 \%$ by 2030 (Pereira et al., 2012; EPE, 2020). Some recommendations should be considered regarding the use of biomass as a source of renewable energy in Brazil: 1) the expansion of the sector cannot be followed by the removal of native vegetation for forestry; economic stimuli must be provided to convert areas of low use, such as abandoned pastures, for the production of plant biomass (Alkimim and Clarke, 2018); 2) the use of biomass for the production of electric energy competes with its use for the production of ethanol, therefore, depending on the supply and demand of fuel and the climatic conditions for plant growth, shortages in the availability of biomass for electric generation may be observed (Lap et al., 2020); 3) poor working conditions were already observed in sugarcane plantation areas in Brazil (Martinelli and Filoso, 2008).

Wind power generation is a complementary source of energy to hydroelectric power in Brazil due to strong winds throughout the year, especially in periods of low rainfall (Pao and $\mathrm{Fu}, 2013$ ). In Brazil, the expansion of wind energy has advantages over biomass and hydroelectricity, as it does not compete with fuel production and predicted changes in the climate should favor wind energy generation (de Jong et al., 2019). On the negative side, wind energy generation is more unpredictable throughout time as it is dependent on wind patterns that vary throughout the seasons and between different years. To mitigate random effects of wind generation, Brazil reformed the electricity market moving from feed-in tariffs in the early 2000 to the current 
auction process (Rego and Ribeiro, 2018). It resulted in an accelerated growth of the contribution of wind energy to the matrix in the last 10 years, since in 2011 wind energy generation was only 2,705 MWh or less than 5\% of that generated in 2020 (Rego and Ribeiro, 2018; EPE, 2021). Currently, wind energy represents $8.8 \%$ of electricity generation in Brazil (57 TWh; EPE, 2021) and it should double by 2030 (EPE, 2020). About $85 \%$ of the potential for wind power generation in Brazil is in the Northeast Region, which is the Brazilian region with the lowest human development index and with the greatest threats to water security (Figure 1C). In this sense, it is expected that the increase in wind electricity generation will boost the region's socio-economic development (de Jong et al., 2017) if social conflicts are avoided (Backhouse and Lehmann, 2020). The increase in wind energy generation must not increase the environmental degradation of the region, since many areas suitable for wind energy are also priority areas for conservation (Neri et al., 2019).

\section{Promoting Mixed Policies to Ensure Multi-Sector Engagement}

Policy mixes considering the multiple dimensions of water resources are paramount to the water-food-energy-ecosystem nexus (Mercure et al., 2019; Sterner et al., 2019). In Brazil, the National Policy on Payment for Environmental Services (cited above) and the Water for All are two examples of policy mixes (Aleixo et al., 2019; Jepson et al., 2021). Established in 2011 and severely reduced in 2019, the Water for All Program aimed to supply water for rural areas of Brazilian drylands, located mainly in the Northeast Region and in the northern part of the Southeast Region. The previously cited "Cistern Program" is intrinsically connected to the Water for All Program. The Water for All Program is coordinated by the Ministry of National Integration, and the Ministries of Health, Environment, Cities, and Social Development were in the mix. In sum, the Water for All Program integrated the five Ministries to develop police mixes related to food and nutrition security, water and public water supply infrastructure, health and environment, and regulation of water use in the region.

Although the management and conservation of water resources are already addressed in several Brazilian laws and regulations, including the comprehensive National Water Resources Policy, these laws and regulations prioritize use by specific sectors and thus often diverge rather than converge in a multisectoral scenario (see review in Mercure et al., 2019, Paim et al., 2020). Cultural and biotic dimensions of water resources are often neglected. Due to sectorial emphasis, some recent political setbacks have occurred. In 2019 more than 430 new pesticides were allowed to be used in agriculture, many of which are prohibited in the European Union due to toxicity to aquatic biota (Braga et al., 2020). We proposed that new integrated policies and policy mixes should account for 1) the economic and societal benefits of the conservation or integrative use of aquatic environments, including small wetlands, 2) the potential multiple uses and integrated management of water bodies when designing PAs, and 3) the impact of fertilizers, herbicides and hormones on the aquatic biodiversity and downstream uses of aquatic resources.

\section{CONCLUSION}

Brazil can use its abundant water resources to pave its way towards sustainability. Here, we exemplified under- or unacessed possibilities in the Brazilian development agenda based on the water-food-energy-ecosystem nexus approach that can be implemented on the way to sustainability. More specifically, we showed that 1) the use of local social technologies and nature-based solutions (e.g., cisterns in semi-arid regions and constructed wetlands in small cities and vulnerable areas) will improve human well-being, food production and environmental protection by increasing the quality, quantity and predictability of water resources; 2) focusing on small wetlands to increase protected areas and designing priority areas considering freshwater ecosystems will benefit environmental preservation with synergistic effects on food production, hydropower generation and human well-being improvement; 3) in-stream hydropower turbines are a suitable low-cost solution for energy production in sparsely located communities of water abundant areas, whose implementation will positive impact human wellbeing, food production, income generation and pollution control; and 4) diversifying the Brazilian energetic matrix hydropower and other renewable energy sources, such as biomass and wind, will secure present and future energy demands besides preserving biodiversity and improving human well-being. We also postulate that, due to the characteristics of Brazilian water resources management, new policy mixes that integrate multiple sectors will be key to implementing public policies that increase synergism and potentially reduce negative trade-offs among sectors. In this sense, two successful water resource management programs (Water for All Program and Payment for Ecosystem Services Program) can exemplify the preparation of future policy mixes.

The Brazilian situation regarding superficial water resources is perhaps unique in the world, but the recommendations presented here are valid for other countries. For example, community cisterns are a low-cost solution for capturing and storing water and can be used in countries or regions with low water availability, such as in SubSaharan Africa. In fact, the "1 million cisterns for the Sahel" launched in 2019 by FAO was mirrored in the Brazilian Cistern Program. Constructed wetlands are low-cost green solutions for sewage treatment in vulnerable areas and small towns, particularly in tropical regions where plant growth is little affected by seasonal climate change. Using wetlands to increase protected areas is an alternative for countries that still have a percentage of protected area below $17 \%$, as proposed in Aichi Target 11. In-stream turbines have already been used in some countries with high rainfall and accentuated relief, such as areas that drain the Andes and the Himalayas. Additionally, these recommendations can also inspire other countries to apply other social and green technologies supported by an institutional framework based on the nexus approaches to solve water-related problems.

Brazil has been facing several setbacks in its socioenvironmental agenda in a clear opposite direction to what we have proposed here. More than 50 legislative acts have 
weakened the environmental legislation during the current administration (Vale et al., 2021). Among the changes implemented by the current government are the reduction of funds for the Cisterns Program, the change in the management of protected areas and the reduction of environmental fines (Vale et al., 2021). The definition of riparian protected areas established by the NVPL is currently under discussion due to real estate speculation. In parallel, the Southeast and Midwest regions of Brazil have been experiencing one of the worst droughts in recent history, and the water reservoirs for several hydroelectric plants are at historic lows. The weakening of the environmental agenda, on the one hand, and the increase in dependence on less-available water resources, on the other, put the management of Brazilian water resources in check and should provide new avenues for the development and application of low-cost solutions that serve multiple sectors in the future. The recommendations proposed here are timely in this scenario. Finally, considering that water is an important asset that integrates multiple dimensions of human wellbeing and can promote sustainability, we reinforce the importance of water to sustain the leading position of Brazil on global agendas such as those related to clean energy, food production and biodiversity conservation.

\section{REFERENCES}

Aleixo, B., Pena, J. L., Heller, L., and Rezende, S. (2019). Infrastructure Is a Necessary but Insufficient Condition to Eliminate Inequalities in Access to Water: Research of a Rural Community Intervention in Northeast Brazil. Sci. Total Environ. 652, 1445-1455. doi:10.1016/j.scitotenv.2018.10.202

Alkimim, A., and Clarke, K. C. (2018). Land Use Change and the Carbon Debt for Sugarcane Ethanol Production in Brazil. Land Use Policy 72, 65-73. doi:10.1016/j.landusepol.2017.12.039

Almeida, R. M., Shi, Q., Gomes-Selman, J. M., Wu, X., Xue, Y., Angarita, H., et al. (2019). Reducing Greenhouse Gas Emissions of Amazon Hydropower with Strategic Dam Planning. Nat. Commun. 10, 4281. doi:10.1038/s41467-01912179-5

ANA (2020). Conjuntura Dos Recursos Hidricos No Brasil - 2020. Brasília, Brazil: Agência Nacional das Águas. Available at: http://conjuntura.ana.gov.br/.

ANA (2021). Programa Produtor de Água. Brasília, Brazil: Agência Nacional das Águas. Available at: https://www.gov.br/ana/pt-br/acesso-a-informacao/acoese-programas/programa-produtor-de-agua.

Arnaiz, M., Cochrane, T. A., Hastie, R., and Bellen, C. (2018). Micro-hydropower Impact on Communities' Livelihood Analysed with the Capability Approach. Energ. Sustain. Develop. 45, 206-210. doi:10.1016/j.esd.2018.07.003

Azevedo-Santos, V. M., Frederico, R. G., Fagundes, C. K., Pompeu, P. S., Pelicice, F. M., Padial, A. A., et al. (2019). Protected Areas: A Focus on Brazilian Freshwater Biodiversity. Divers. Distrib. 25, 442-448. doi:10.1111/ddi.12871

Backhouse, M., and Lehmann, R. (2020). New 'renewable' Frontiers: Contested palm Oil Plantations and Wind Energy Projects in Brazil and Mexico. J. Land Use Sci. 15, 373-388. doi:10.1080/1747423X.2019.1648577

Bijl, D. L., Bogaart, P. W., Dekker, S. C., and van Vuuren, D. P. (2018). Unpacking the Nexus: Different Spatial Scales for Water, Food and Energy. Glob. Environ. Change 48, 22-31. doi:10.1016/j.gloenvcha.2017.11.005

Blanco, C. J. C., Secretan, Y., and Mesquita, A. L. A. (2008). Decision Support System for Micro-hydro Power Plants in the Amazon Region under a Sustainable Development Perspective. Energ. Sustain. Develop. 12, 25-33. doi:10.1016/S0973-0826(08)60435-4

BPBES (2020). "Relatório Temático Água: Biodiversidade, Serviços Ecossistêmicos e Bem-Estar Humano No Brasil," in 1a Edição. Editors P. F. P. Aliny,

\section{DATA AVAILABILITY STATEMENT}

The original contributions presented in the study are included in the article/Supplementary Material, further inquiries can be directed to the corresponding author.

\section{AUTHOR CONTRIBUTIONS}

VF, AP and FS conceived the research. All authors contributed with ideias, data and information to the text. VF wrote the text. All authors reviewed and approved the text.

\section{ACKNOWLEDGMENTS}

Authors are grateful to the Brazilian Platform of Biodiversity and Ecosystem Services (BPBES) for encouraging the preparation of the Thematic Report on Water: Biodiversity, Ecosystem Services and Human Well-Being in Brazil, which supported this publication. Vinicius F. Farjalla and André M. Amado are partially supported by $\mathrm{CNPq}$ Productivity Grants (Proc. $310119 / 2018-9$ and 312772/2020-2, respectively).

F. F. Vinicius, M. F. Bias, A. R. Daniel, A. T. G. Eli, C. S. Eldis, et al. (São Carlos: SP: Editora Cubo), 120. doi:10.4322/978-65-00-00068-9

Braga, A. R. C., de Rosso, V. V., Harayashiki, C. A. Y., Jimenez, P. C., and Castro, Í B. (2020). Global Health Risks from Pesticide Use in Brazil. Nat. Food 1, 312-314. doi:10.1038/s43016-020-0100-3

Butchers, J., Williamson, S., and Booker, J. (2021). Micro-hydropower in Nepal: Analysing the Project Process to Understand Drivers that Strengthen and Weaken Sustainability. Sustainability 13, 1582. doi:10.3390/su13031582

Carvalho, P., and Spataru, C. (2018). Advancing the Implementation of SDGs in Brazil by Integrating Water-Energy Nexus and Legal Principles for Better Governance. SE 3, 277-304. doi:10.22158/se.v3n3p277

Cavalcante, L., Mesquita, P. S., and Rodrigues-Filho, S. (2020). 2nd Water Cisterns: Social Technologies Promoting Adaptive Capacity to Brazilian Family Farmers. Desenvolv. Meio Ambiente 55, 433-450. doi:10.5380/dma.v55i0.73389

da Silva, R. C., de Marchi Neto, I., and Silva Seifert, S. (2016). Electricity Supply Security and the Future Role of Renewable Energy Sources in Brazil. Renew. Sustain. Energ. Rev. 59, 328-341. doi:10.1016/j.rser.2016.01.001

da Mata, D., Emanuel, L., Pereira, V. A., and Sampaio, B. (2021). Climate Adaptation Policies and Infant Health: Evidence from a Water Policy in Brazil. IZA Discussion Paper No. 14295. Available at: https://ssrn.com/ abstract $=3833227$ (Accessed October 15, 2021).

da Silva, J. G., (2019). From Fome Zero to Zero Hunger: A Global Perspective. Rome: FAO. doi:10.4060/CA5524EN

de Jong, P., Barreto, T. B., Tanajura, C. A. S., Kouloukoui, D., Oliveira-Esquerre, K. P., Kiperstok, A., et al. (2019). Estimating the Impact of Climate Change on Wind and Solar Energy in Brazil Using a South American Regional Climate Model. Renew. Energ. 141, 390-401. doi:10.1016/j.renene.2019.03.086

de Jong, P., Dargaville, R., Silver, J., Utembe, S., Kiperstok, A., and Torres, E. A. (2017). Forecasting High Proportions of Wind Energy Supplying the Brazilian Northeast Electricity Grid. Appl. Energ. 195, 538-555. doi:10.1016/ j.apenergy.2017.03.058

Doss-Gollin, J., de Souza Filho, F. d. A., and da Silva, F. O. E. (2016). Analytic Modeling of Rainwater Harvesting in the Brazilian Semiarid Northeast. J. Am. Water Resour. Assoc. 52, 129-137. doi:10.1111/1752-1688.12376

Elabras Veiga, L. B., and Magrini, A. (2013). The Brazilian Water Resources Management Policy: Fifteen Years of success and Challenges. Water Resour. Manage. 27, 2287-2302. doi:10.1007/s11269-013-0288-1 
EPE (2021). Balanço Energético Nacional (BEN) 2020. Brasil: Empresa de Pesquisa Energética, Ministério de Minas e Energia. Available at: https:// www.epe.gov.br/pt/publicacoes-dados-abertos/publicacoes/balanco-energeticonacional-2021.

EPE (2020). Plano Decenal de Expansão de Energia - 2030. Brasil: Empresa de Pesquisa Energética, Ministério de Minas e Energia. Available at: https://www. epe.gov.br/sites-pt/publicacoes-dados-abertos/publicacoes/.

Erinofiardi, E., Gokhale, P., Date, A., Akbarzadeh, A., Bismantolo, P., Suryono, A. F., et al. (2017). A Review on Micro Hydropower in Indonesia. Energ. Proced. 110, 316-321. doi:10.1016/j.egypro.2017.03.146

Farjalla, V. F., Faria, B. M., Rodriguez, D. A., Gomes, E. A. T., Santos, E. C., Sodré, F. N. G. A., et al. (2020). Viviane Dib (Org.). 1a edição. São Carlos, SP: Editora Cubo, 120. doi:10.4322/978-65-00-00068-9

Folke, C., Biggs, R., Norström, A. V., Reyers, B., and Rockström, J. (2016). Socialecological Resilience and Biosphere-Based Sustainability Science. ES 21, 41. doi:10.5751/ES-08748-210341

González-Bravo, R., Marques Bezerra, M. C. M. O., Bezerra, M. O., Coutinho, B., Castillo, J. L. d., Vollmer, D., et al. (2020). Urban sustainability: Analyzing the water-energy nexus in the Guandu river basin, Rio de Janeiro, Brazil. Energ. Rep. 6, 254-260. doi:10.1016/j.egyr.2019.08.053

Gray, L. (2008). Evaluation of Treatment Potential and Feasibility of Constructed Wetlands Receiving Municipal Wastewater in Nova Scotia. Master Dissertation Canada: Environmental Science Program, Dalhousie University. 47

Green, J. M. H., Cranston, G. R., Sutherland, W. J., Tranter, H. R., Bell, S. J., Benton, T. G., et al. (2017). Research Priorities for Managing the Impacts and Dependencies of Business upon Food, Energy, Water and the Environment. Sustain. Sci. 12, 319-331. doi:10.1007/s11625-016-0402-4

Gutiérrez, A. P. A., Engle, N. L., De Nys, E., Molejón, C., and Martins, E. S. (2014). Drought Preparedness in Brazil. Weather Clim. Extremes 3, 95-106. doi:10.1016/j.wace.2013.12.001

Heard, B. R., Miller, S. A., Liang, S., and Xu, M. (2017). Emerging Challenges and Opportunities for the Food-Energy-Water Nexus in Urban Systems. Curr. Opin. Chem. Eng. 17, 48-53. doi:10.1016/j.coche.2017.06.006

Hoff, J. (2011). "Understanding the Nexus," in Background Paper for the Bonn 2011 Conference: The Water, Energy and Food Security Nexus (Stockholm, Sweden: Stockholm Environment Institute).

IBGE (2020). Síntese de indicadores sociais: uma análise das condições de vida da população brasileira. Rio de Janeiro, Brazil: Instituto Brasileiro de Geografia e Estatística, 130.

Jepson, W., Tomaz, P., Santos, J. O., and Baek, J. (2021). A Comparative Analysis of Urban and Rural Household Water Insecurity Experiences during the 2011-17 Drought in Ceará, Brazil. Water Int. 46, 697-722. doi:10.1080/ 02508060.2021.1944543

Junk, W. J., Piedade, M. T. F., Lourival, R., Wittmann, F., Kandus, P., Lacerda, L. D., et al. (2014). Brazilian Wetlands: Their Definition, Delineation, and Classification for Research, Sustainable Management, and protection. Aquat. Conserv. Mar. Freshw. Ecosyst. 24, 5-22. doi:10.1002/aqc.2386

Kaddoura, S., and El Khatib, S. (2017). Review of Water-Energy-Food Nexus Tools to Improve the Nexus Modelling Approach for Integrated Policy Making. Environ. Sci. Pol. 77, 114-121. doi:10.1016/j.envsci.2017.07.007

Kivaisi, A. K. (2001). The Potential for Constructed Wetlands for Wastewater Treatment and Reuse in Developing Countries: A Review. Ecol. Eng. 16, 545-560. doi:10.1016/S0925-8574(00)00113-0

Kuriqi, A., Pinheiro, A. N., Sordo-Ward, A., Bejarano, M. D., and Garrote, L. (2021). Ecological Impacts of Run-Of-River Hydropower Plants-Current Status and Future Prospects on the Brink of Energy Transition. Renew. Sustain. Energ. Rev. 142, 110833. doi:10.1016/j.rser.2021.110833

Lap, T., Benders, R., van der Hilst, F., and Faaij, A. (2020). How Does the Interplay between Resource Availability, Intersectoral Competition and Reliability Affect a Low-Carbon Power Generation Mix in Brazil for 2050? Energy 195, 116948. doi:10.1016/j.energy.2020.116948

Latrubesse, E. M., Arima, E. Y., Dunne, T., Park, E., Baker, V. R., d'Horta, F. M., et al. (2017). Damming the Rivers of the Amazon basin. Nature 546, 363-369. doi:10.1038/nature22333

Leal, C. G., Lennox, G. D., Ferraz, S. F. B., Ferreira, J., Gardner, T. A., Thomson, J. R., et al. (2020). Integrated Terrestrial-Freshwater Planning Doubles Conservation of Tropical Aquatic Species. Science 370, 117-121. doi:10.1126/science.aba7580
Lima, M. A., Mendes, L. F. R., Mothé, G. A., Linhares, F. G., de Castro, M. P. P., da Silva, M. G., et al. (2020). Renewable Energy in Reducing Greenhouse Gas Emissions: Reaching the Goals of the Paris Agreement in Brazil. Environ. Develop. 33, 100504. doi:10.1016/j.envdev.2020.100504

Lindoso, D., Eiró, F., Bursztyn, M., Rodrigues-Filho, S., and Nasuti, S. (2018). Harvesting Water for Living with Drought: Insights from the Brazilian Human Coexistence with Semi-aridity Approach towards Achieving the Sustainable Development Goals. Sustainability 10, 622. doi:10.3390/ su 10030622

Liu, J., Hull, V., Godfray, H. C. J., Tilman, D., Gleick, P., Hoff, H., et al. (2018a). Nexus Approaches to Global Sustainable Development. Nat. Sustain. 1, 466-476. doi:10.1038/s41893-018-0135-8

Liu, J., Mao, G., Hoekstra, A. Y., Wang, H., Wang, J., Zheng, C., et al. (2018b). Managing the Energy-Water-Food Nexus for Sustainable Development. Appl. Energ. 210, 377-381. doi:10.1016/j.apenergy.2017.10.064

Lucena, A. F. P., Hejazi, M., Vasquez-Arroyo, E., Turner, S., Köberle, A. C., Daenzer, K., et al. (2018). Interactions between Climate Change Mitigation and Adaptation: The Case of Hydropower in Brazil. Energy 164, 1161-1177. doi:10.1016/j.energy.2018.09.005

Mahlknecht, J., González-Bravo, R., and Loge, F. J. (2020). Water-energy-food Security: A Nexus Perspective of the Current Situation in Latin America and the Caribbean. Energy 194, 116824. doi:10.1016/j.energy.2019.116824

Martinelli, L. A., and Filoso, S. (2008). Expansion of Sugarcane Ethanol Production in Brazil: Environmental and Social Challenges. Ecol. Appl. 18, 885-898. doi:10.1890/07-1813.1

Matricardi, E. A. T., Skole, D. L., Costa, O. B., Pedlowski, M. A., Samek, J. H., and Miguel, E. P. (2020). Long-term forest Degradation Surpasses Deforestation in the Brazilian Amazon. Science 369, 1378-1382. doi:10.1126/science.abb3021

Mayer, A., Castro-Diaz, L., Lopez, M. C., Leturcq, G., and Moran, E. F. (2021). Is Hydropower worth it? Exploring Amazonian Resettlement, Human Development and Environmental Costs with the Belo Monte Project in Brazil. Energ. Res. Soc. Sci. 78, 102129. doi:10.1016/j.erss.2021.102129

MDR (2019). Plano Nacional de Saneamento Básico. Brasília, Brazil: Ministério do Desenvolvimento Regional.

Medeiros, R., Young, C. E. F., Pavese, H. B., and Araújo, F. F. S. (2011). The Contribution of Brazilian Conservation Units to the National Economy: Executive Summary. Brasília, Brazil: UNEP-WCMC.

Mercure, J.-F., Paim, M. A., Bocquillon, P., Lindner, S., Salas, P., Martinelli, P., et al. (2019). System Complexity and Policy Integration Challenges: The Brazilian Energy- Water-Food Nexus. Renew. Sustain. Energ. Rev. 105, 230-243. doi:10.1016/j.rser.2019.01.045

Milhorance, C., Le Coq, J.-F., and Sabourin, E. (2021). Dealing with Cross-Sectoral Policy Problems: An Advocacy Coalition Approach to Climate and Water Policy Integration in Northeast Brazil. Policy Sci. 54, 557-578. doi:10.1007/ s11077-021-09422-6

Miranda, G. M., and Reynard, E. (2020). Integrated Water Resources Management in Federations: the Examples of Brazil and Switzerland. Water 12, 1914 doi:10.3390/w12071914

Moran, E. F., Lopez, M. C., Moore, N., Müller, N., and Hyndman, D. W. (2018). Sustainable Hydropower in the 21st century. Proc. Natl. Acad. Sci. USA 115, 11891-11898. doi:10.1073/pnas.1809426115

Nag, A. K., and Sarkar, S. (2021). Techno-economic Analysis of a Microhydropower Plant Consists of Hydrokinetic Turbines Arranged in Different Array Formations for Rural Power Supply. Renew. Energ. 179, 475-487. doi:10.1016/j.renene.2021.07.067

Narzetti, D. A., and Marques, R. C. (2021). Access to Water and Sanitation Services in Brazilian Vulnerable Areas: The Role of Regulation and Recent Institutional Reform. Water 13, 787. doi:10.3390/w13060787

Nelson, M., Odum, H. T., Brown, M. T., and Alling, A. (2001). "Living off the Land": Resource Efficiency of Wetland Wastewater Treatment. Adv. Space Res. 27, 1547-1556. doi:10.1016/S0273-1177(01)00246-0

Neri, M., Jameli, D., Bernard, E., and Melo, F. P. L. (2019). Green versus green? Adverting Potential Conflicts between Wind Power Generation and Biodiversity Conservation in Brazil. Perspect. Ecol. Conserv. 17, 131-135. doi:10.1016/j.pecon.2019.08.004

Nogueira, M. F. M., Lima, C. U. d. S., and Ribeiro, R. R. P. (1993). The Use of Small Hydroelectric Power Plants in the Amazon. Renew. Energ. 3, 907-911. doi:10.1016/0960-1481(93)90049-M 
Obrecht, A., Pham-Truffert, M., Spehn, E., Payne, D., Altermatt, F., Fischer, M., et al. (2021). Achieving the SDGs with Biodiversity, 16. Bern, Switzerland: Swiss Academies Factsheet. Zenodo. doi:10.5281/zenodo.4457298

Okot, D. K. (2013). Review of Small Hydropower Technology. Renew. Sustain. Energ. Rev. 26, 515-520. doi:10.1016/j.rser.2013.05.006

Pacheco, A. A., Neves, A. C. O., and Fernandes, G. W. (2018). Uneven Conservation Efforts Compromise Brazil to Meet the Target 11 of Convention on Biological Diversity. Perspect. Ecol. Conserv. 16, 43-48. doi:10.1016/j.pecon.2017.12.001

Paim, M. A., Salas, P., Lindner, S., Pollitt, H., Mercure, J. F., Edwards, N. R., et al. (2020). Mainstreaming the Water-Energy-Food Nexus Through Nationally Determined Contributions (NDCs): The Case of Brazil. Clim. Policy 20, 163-178. doi:10.1080/14693062.2019.1696736

Pao, H.-T., and Fu, H.-C. (2013). Renewable Energy, Non-renewable Energy and Economic Growth in Brazil. Renew. Sustain. Energ. Rev. 25, 381-392. doi:10.1016/j.rser.2013.05.004

Pereira, M. G., Camacho, C. F., Freitas, M. A. V., and Silva, N. F. d. (2012). The Renewable Energy Market in Brazil: Current Status and Potential. Renew. Sustain. Energ. Rev. 16, 3786-3802. doi:10.1016/j.rser.2012.03.024

Pires, A. P. F., Rezende, C. L., Assad, E. D., Loyola, R., and Scarano, F. R. (2017). Forest Restoration Can Increase the Rio Doce Watershed Resilience. Perspect. Ecol. Conserv. 15, 187-193. doi:10.1016/j.pecon.2017.08.003

Pires, A. P. F., Rodriguez Soto, C., and Scarano, F. R. (2021). Strategies to Reach Global Sustainability Should Take Better Account of Ecosystem Services. Ecosys. Serv. 49, 101292. doi:10.1016/j.ecoser.2021.101292

Quintas, M. C., Blanco, C. J. C., and Amarante Mesquita, A. L. (2012). Analysis of Two Schemes Using Micro Hydroelectric Power (MHPs) in the Amazon with Environmental Sustainability and Energy and Economic Feasibility. Environ. Dev. Sustain. 14, 283-295. doi:10.1007/s10668-011-9322-8

Rego, E. E., and de Oliveira Ribeiro, C. (2018). Successful Brazilian Experience for Promoting Wind Energy Generation. Electric. J. 31, 13-17. doi:10.1016/ j.tej.2018.02.003

Rezende, C. L., Scarano, F. R., Assad, E. D., Joly, C. A., Metzger, J. P., Strassburg, B. B. N., et al. (2018). From Hotspot to Hopespot: An Opportunity for the Brazilian Atlantic Forest. Perspect. Ecol. Conserv. 16, 208-214. doi:10.1016/ j.pecon.2018.10.002

Ribeiro, H. M., and Morato, J. R. (2020). Social Environmental Injustices against Indigenous Peoples: the Belo Monte Dam. Dpm 29, 865-876. doi:10.1108/ DPM-02-2020-0033

Richards, R. C., Rerolle, J., Aronson, J., Pereira, P. H., Gonçalves, H., and Brancalion, P. H. S. (2015). Governing a pioneer Program on Payment for Watershed Services: Stakeholder Involvement, Legal Frameworks and Early Lessons from the Atlantic forest of Brazil. Ecosys. Serv. 16, 23-32. doi:10.1016/ j.ecoser.2015.09.002

Sampaio, P. R. P., and Sampaio, R. S. R. (2020). The Challenges of Regulating Water and Sanitation Tariffs under a Three-Level Shared-Authority Federalism Model: The Case of Brazil. Utilities Policy 64, 101049. doi:10.1016/j.jup.2020.101049

Santos, M. J., Ferreira, P., Araújo, M., Portugal-Pereira, J., Lucena, A. F. P., and Schaeffer, R. (2017). Scenarios for the Future Brazilian Power Sector Based on a Multi-Criteria Assessment. J. Clean. Prod. 167, 938-950. doi:10.1016/ j.jclepro.2017.03.145

Scherer, L., Behrens, P., de Koning, A., Heijungs, R., Sprecher, B., and Tukker, A. (2018). Trade-offs between Social and Environmental Sustainable Development Goals. Environ. Sci. Pol. 90, 65-72. doi:10.1016/j.envsci.2018.10.002

Silva, T. A., Ferreira, J., Calijuri, M. L., dos Santos, V. J., Alves, S. d. C., and Castro, J. d. S. (2021). Efficiency of Technologies to Live with Drought in Agricultural Development in Brazil's Semi-arid Regions. J. Arid Environ. 192, 104538. doi:10.1016/j.jaridenv.2021.104538
Sloan, P., Simons-Kaufman, C., and Legrand, W. (2012). Sustainable Hospitality and Tourism as Motors for Development: Case Studies from Developing Regions of the World. Oxfordshire, England, UK: Routledge. ISBN 9781138081505.

Sterner, T., Barbier, E. B., Bateman, I., van den Bijgaart, I., Crépin, A.-S., Edenhofer, O., et al. (2019). Policy Design for the Anthropocene. Nat. Sustain. 2, 14-21. doi:10.1038/s41893-018-0194-x

Tedesco, P. A., Beauchard, O., Bigorne, R., Blanchet, S., Buisson, L., Conti, L., et al. (2017). A Global Database on Freshwater Fish Species Occurrence in Drainage Basins. Sci. Data 4, 170141. doi:10.1038/sdata.2017.141

Teixeira, T. R., Ribeiro, C. A. A. S., Santos, A. S., Marcatti, G. E., Lorenzon, A. S., Castro, N. L. M., et al. (2018). Forest Biomass Power Plant Installation Scenarios. Biomass Bioenergy 108, 35-47. doi:10.1016/j.biombioe.2017.10.006

Trimble, M., Jacobi, P. R., Olivier, T., Pascual, M., Zurbriggen, C., Garrido, L., et al. (2021). "Reconfiguring Water Governance for Resilient Social-Ecological Systems in South America," in Water Resilience (Cham: Springer), 113-135. doi:10.1007/978-3-030-48110-0_6

Vale, M. M., Berenguer, E., Argollo de Menezes, M., Viveiros de Castro, E. B., Pugliese de Siqueira, L., and Portela, R. d. C. Q. (2021). The COVID-19 Pandemic as an Opportunity to Weaken Environmental protection in Brazil. Biol. Conserv. 255, 108994. doi:10.1016/j.biocon.2021.108994

van Els, R. H., and Brasil Junior, A. C. P. (2015). The Brazilian Experience with Hydrokinetic Turbines. Energ. Proced. 75, 259-264. doi:10.1016/ j.egypro.2015.07.328

VanZwieten, J., McAnally, W., Ahmad, J., Davis, T., Martin, J., Bevelhimer, M., et al. (2015). In-stream Hydrokinetic Power: Review and Appraisal. J. Energ. Eng. 141 (3), 04014024. doi:10.1061/(ASCE)EY.1943-7897.0000197

Viani, R. A. G., Braga, D. P. P., Ribeiro, M. C., Pereira, P. H., and Brancalion, P. H. S. (2018). Synergism between Payments for Water-Related Ecosystem Services, Ecological Restoration, and Landscape Connectivity within the Atlantic Forest Hotspot. Trop. Conserv. Sci. 11, 194008291879022. doi:10.1177/1940082918790222

Vörösmarty, C. J., McIntyre, P. B., Gessner, M. O., Dudgeon, D., Prusevich, A., Green, P., et al. (2010). Global Threats to Human Water Security and River Biodiversity. Nature 467, 555-561. doi:10.1038/nature09440

Wallington, K., and Cai, X. (2017). The Food-Energy-Water Nexus: A Framework to Address Sustainable Development in the Tropics. Trop. Conserv. Sci. 10, 194008291772066. doi:10.1177/1940082917720665

Wood, S. L. R., Jones, S. K., Johnson, J. A., Brauman, K. A., Chaplin-Kramer, R., Fremier, A., et al. (2018). Distilling the Role of Ecosystem Services in the Sustainable Development Goals. Ecosys. Serv. 29, 70-82. doi:10.1016/j.ecoser.2017.10.010

Conflict of Interest: The authors declare that the research was conducted in the absence of any commercial or financial relationships that could be construed as a potential conflict of interest.

Publisher's Note: All claims expressed in this article are solely those of the authors and do not necessarily represent those of their affiliated organizations, or those of the publisher, the editors and the reviewers. Any product that may be evaluated in this article, or claim that may be made by its manufacturer, is not guaranteed or endorsed by the publisher.

Copyright (C) 2021 Farjalla, Pires, Agostinho, Amado, Bozelli, Dias, Dib, Faria, Figueiredo, Gomes, Lima, Mormul, Ometto, Panosso, Ribeiro, Rodriguez, Sabino, Scofield and Scarano. This is an open-access article distributed under the terms of the Creative Commons Attribution License (CC BY). The use, distribution or reproduction in other forums is permitted, provided the original author(s) and the copyright owner(s) are credited and that the original publication in this journal is cited, in accordance with accepted academic practice. No use, distribution or reproduction is permitted which does not comply with these terms. 